IRA-International Journal of Management \&

Social Sciences

ISSN 2455-2267; Vol.17, Issue 02 (Q.2 2021)

Pg. no. 56-63.

IRA Academico Research

\title{
Green Marketing: A Descriptive Analysis of its Influence on Consumer Buying Behavior
}

\author{
Fhrizz S. De Jesus ${ }^{1 \# ~(1), ~ J e v e r l y n ~ B . ~ R a m o s ~}{ }^{2}$ (D), Mariel T. Cunanan ${ }^{3}$ (iD) \\ 1,2,3Nueva Ecija University of Science And Technology, Atate Campus, Palayan City, \\ Philippines.
}

${ }^{\#}$ corresponding author

Type of Work: Peer Reviewed.

DOl: https://dx.doi.org/10.21013/jmss.v17.n2.p5

\section{How to cite this paper:}

Fhrizz S. De Jesus et al. (2021). Green Marketing: A Descriptive Analysis of its Influence on Consumer Buying Behavior. IRA-International Journal of Management \& Social Sciences (ISSN 2455-2267), 17(2), 5663. DOl: https://dx.doi.org/10.21013/jmss.v17.n2.p5

(C) IRA Academico Research.

(cc) BY-NC This work is licensed under a Creative Commons Attribution-NonCommercial 4.0 International License subject to a proper citation to the publication source of the work.

Disclaimer: The scholarly papers as reviewed and published by IRA Academico Research are the views and opinions of their respective authors and are not the views or opinions of IRA Academico Research. IRA Academico Research disclaims any harm or loss caused due to the published content to any party.

IRA Academico Research is an institutional publisher member of Publishers International Linking Association Inc. (PILA-CrossRef), USA. IRA Academico Research is an institutional signatory to the Budapest Open Access Initiative. Hungary advocating the open access of scientific and scholarly knowledge. IRA Academico Research is a registered content provider under Open Access Initiative Protocol for Metadata Harvesting (OAl-PMH).

The journal is indexed \& included in WorldCat Discovery Service (USA), CrossRef Metadata Search (USA), WorldCat (USA), OCLC (USA), Open J-Gate (India), EZB (Germany) Scilit (Switzerland), Airiti (China), Bielefeld Academic Search Engine (BASE) of Bielefeld University, Germany, PKP Index of Simon Fraser University, Canada. 


\section{ABSTRACT}

Green marketing has become a very important marketing concept in recent years, and it has proven to be effective in promoting and reinforcing the concept of environmental conservation and sustainable development. The objective of this descriptive study was to determine the influence of green marketing on buying behaviour of consumers and their views and expectations towards green product and this study aim to assist consumers in Palayan City, Philippines by raising product awareness through ads, with the goal of changing individual purchasing habits, which can have an effect on environmental welfare and also to understand environmental friendly products' availability and the impact of advertisers' marketing campaigns in relation to consumers. As to its findings, most of the respondent agreed that humans must live in harmony with nature in order to survive. Also, the respondents believed that no consumers or buyers should frequently buy which can be refilled, and they are highly in favour that they feel good about buying green brands causing less damage to our environment. It also revealed that using an eco-friendly product has the most impact of green marketing on consumer buying decision that contributes for the environment safety, they encourage patronizing green marketing and using eco-friendly products to lessen the negative impact in our environment. Finally, the researchers recommend strengthening the campaign on green marketing practice through the use of different social media platforms. These platforms will help to connect with the customers and increase awareness of the crisis facing by the environment.

Keywords: Green Marketing, Sustainability, Environment, Environmental Friendly

\section{INTRODUCTION}

Green marketing is the process of creating and promoting goods and services that meet the needs of consumers who prefer products of good quality, performance and convenient products at an affordable price that do not harm the environment. Green marketing has become a very important marketing concept in recent years, and it has proven to be effective in promoting and reinforcing the concept of environmental conservation and sustainable development for both consumers and businesses.

Ever since then, the sustainability concerns related to the integration of environmental and economic goals have become the forethought of the leading business firms, and they are increasingly adopting green practices. Market awareness of green goods in emerging economies like India is still in its infancy [1]. Green marketing is underappreciated by consumers, who equate it with social responsibility programs. They analyze the effect of collective self-esteem, moral and informative beliefs, and social power on Indian consumers' green buying decisions in addition to this consumers' knowledge of eco-products has the greatest impact on channelling environmental interest into eco-product purchasing intention. The results indicate that normative values, social influence, and group esteem affect consumers' green purchase behaviour. The findings can aid businesses in raising awareness of green marketing and products, resulting in increased profits [2].

The research objective was to determine the influence of green marketing on buying behaviour of consumers and their views and expectations towards green product and this study aim to assist consumers by raising product awareness through ads, with the goal of changing individual purchasing habits, which can have an effect on environmental welfare and also to understand environmental friendly products' availability and the impact of advertisers' marketing campaigns in relation to consumers.

This study was based on "The Impact of Green Marketing Practices on Consumer Buying Decision" this study is from India by Maheshwari (2014) which stated that Customer's attitudes are changing towards the environment to encourage innovation for conservation and the benefits from this source of innovation are certain to outlive our current generation. This paper investigates consumer beliefs and attitude on environment protection and their purchasing behaviour of eco-friendly products. This paper identifies that consumers are not exposed enough to green product marketing communication and suggests the greater use of marketing and brands to promote and sell products that are environmentally friendly and function effectively. The paper suggests that the Indian market for greener products could be exploited more within consumer groups that have pro-environmental values.

Additionally, this study was based also on the study entitled "The Impact of Green Marketing Practices on Consumer Buying Decision" by J. Fonseca (2015). Colour can be one of the most important characteristics to impulse customers to buy certain products. So, organizations have been using green marketing practices, as 
transforming products into more friendly for the environment and incorporating features that cause less impact in it. These products are emerging as differentiating products, in order to follow up with these value-conscious customers, whose consumptions patterns and buying-decision have been evolving. Customers have become more and more concerned with environmental issues and they want to have an active role in order to diminish the impact their actions have on the environment.

Therefore, the purpose of this research is to investigate the customers' perception of organizations attitudes when these engage in green marketing practices, and also how it affects and, in ways, shapes customers buying-decision when aware of the impact of their actions in the environment. This study was based on the literature review and was conducted a questionnaire to 250 customers. The analysis of the results shows customers tend to be influenced by green marketing practices and are more motivated when aware of environmental issues. However, customers are still not very clear about companies' intentions, when engaging in these approaches.

\section{Theoretical Framework}

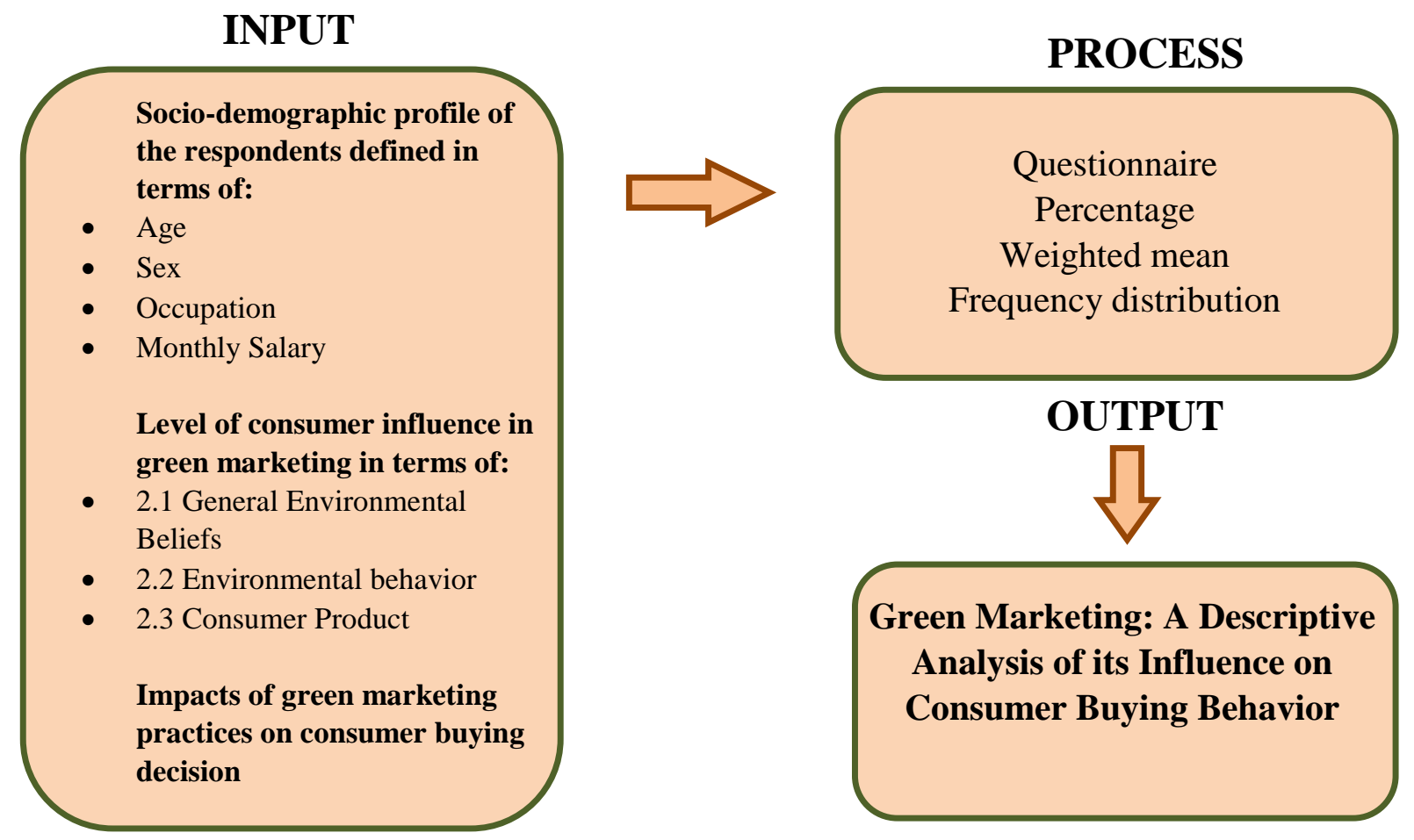

Figure 1 Research Paradigm

\section{METHODOLOGY}

\section{Research Design}

The study utilized the descriptive analysis to assess the level of influence of green marketing on consumer buying behaviour. This design was quantitative, using frequencies, percentages, weighted mean, or other statistical analyses to determine its influence.

Descriptive analysis is one of three basic types of research design. It is a quantitative research method considered conclusive and used to test specific hypotheses and describe characteristics or functions. Descriptive research should have a clear and accurate research question/problem [3]. 


\section{Study Locale}

This research was conducted in the City of Palayan, Nueva Ecija where the respondents were identified. The lists of the consumers in Palayan City, Nueva Ecija Profile were extracted from the PhilAtlas website. The respondents of this study came from the different barangays found in the Palayan City of Nueva Ecija.

\section{Participant Selection}

To choose qualified participants, the researchers used a voluntary sampling technique. This sampling method is one of the main types of non-probability sampling methods. A voluntary sample is made up of people who self-select into the survey. Often, these folks have a strong interest in the main topic of the survey; it is a voluntarily participated in the survey and willing to provide personal judgement [4].

The total sample sizes of the respondents of the study are 376 from the total population of 17,135 . This study uses the Raosoft application to determine the sample size with a $95 \%$ confidence level and $5 \%$ error margin.

\section{Data Collection}

\section{Interview Process}

The three hundred seventy-six participants were interviewed to determine their occupational classification and perception of green marketing. Survey questionnaires are a set of questions to accomplish the objectives of the study; participants encourage completing them over the internet via a Google form. The online survey questionnaires constructed in the Google form consisted of parts; the first includes the socio-demographic profile of the consumers, while the remaining assess the level of influence of Green marketing to consumer and the impact of green marketing on consumer buying behaviour. The researchers scheduled the interview based on the availability of participants. After the distribution, the information that will be gathered from the answered questionnaire will be tallied for further interpretation.

\section{Participation observation}

During data-gathering and participants' interviews, notes were also collected as the researchers observe the participants and environments. This process aims to describe the characteristics of the participants in their environment that can support the data being gathered. Data collected from the interview and the notes were compared to identify the emerging themes that answered the research questions

\section{Confidentiality of data}

The confidentiality of the data gathered was assured to the participants. During the data-gathering, informed consent was obtained from all of the respondents. They are well-informed of the purpose of the study and their rights to withdraw, and they all agreed to participate in the study. All personal and work information and accounts of the participants are protected and treated with confidentiality by preserving their anonymity.

\section{Data Analysis}

The data collected from the locale were encoded, tallied, and analyzed. Statistical tools such as Percentage, Frequency Distribution, Weighted Mean, and Thematic Analysis were used in analyzing the data gathered.

\section{RESULTS AND DISCUSSION}

The researchers discuss the findings in the profile of the respondents for green marketing in buying behaviour of consumers.

\section{Profile of the respondents}

\section{Age}

The ages 25-29 years old are the most number of respondents. This shows that green marketing is patronized by the young ages. As added, green marketing is the process of promoting products or services based on their environmental benefits. It means that young ages now are more into environmental safety in terms of their buying behaviour.

Furthermore, respondents at young ages preferred green products over standard alternatives. However, they were price sensitive which affected their purchasing decision. In line with this, it is evident that green marketing or eco- 
friendly products or services will continue to be in demand in the market. According to the respondents, they are the ones who mostly purchase the needs of their family.

This statistic shows the share of adults in the United States who were using social networks as of February 2019, sorted by age group. 90 per cent of people between the ages of 18 and 29 used social media during that time period [5].

\section{Sex}

The majority of the respondents were female. Female respondents agreed that we must patronize environmental friendly products. Both males and females are becoming more concerned and aware of the natural environment.

Males and females have maybe a difference in their attitudes towards eco-friendly products that they will purchase. It was found that female consumers having different age and occupation do not have a different attitude towards green products, but the income has an impact on it. In line with this, it is evident that females highly patronizing green marketing.

Women think differently from men because there are biological, neurological, and behavioural variations between the brains of men and women. These distinctions have an effect on their shopping habits because female have their own power to control the money that they spend [6].

\section{Occupation}

The individuals with no work have the most number in the gathered data, second are the construction workers, third is the vendors, fourth is the students and fifth are the online sellers. It simply appears that all types of consumers believed that we had a responsibility to care for the environment. A further number of respondents also indicated that they had modified their behaviour, including their purchasing behaviour due to environmental reasons.

Online sellers and other workers are into green marketing because it is safe for the environment and it can lessen the damage in our society. In line with this, occupations that got the most numbers of respondents are evident that they are into green marketing and supporting eco-friendly products and services.

Poverty is primarily due to the low earning capacity of the poor and to their limited access to regular and productive jobs. Low education among the poor and a lack of productive employment prospects are the two interrelated root causes of in-work poverty [7].

\section{Monthly Salary}

The majority of respondents have a monthly salary of 5,000 (five thousand) and below. The above findings indicate that the common average monthly salary of respondents' was based on their occupation. According to the respondents, they want green products, but they don't tend to buy them because they have no enough budget.

Those with lower income levels were more likely to demonstrate environmentally friendly behaviours [8]. Consumers having low-income level are not affected by price as thought; they are affected by promotion activities [9].

\section{Level of Influence of Green Marketing on Consumers}

\section{General Environmental Beliefs}

The respondents agreed that humans must live in harmony with nature in order to survive which got the most number of respondents, followed by the second most number which indicated that to maintain a healthy economy; we have to control industrial growth. As added, unfortunately, the majority of people believe that green marketing refers solely to the promotion or advertising of products with environmental characteristics.

In our traditional native view of the world, everything is parallel in nature. Most of our things come directly from the earth. The earth is thought of as a mother because she provides all that we need. And she is deeply revered. In line with this, occupations that got the most number of respondents believed that when humans lived in the harmony with nature we can all survive. 
According to the respondent's people are a part of nature and is not only just set of resources it is also to live peacefully and in order to have a healthy life. A failure to recognize this has resulted in humanity experiencing a crisis "rooted in the increasingly virulent relationship between human beings and the rest of nature [10]. Humans and nature are deeply and interdependently interconnected. They communicate reciprocally over time and influence each other in a relationship characterized by continuous change.

\section{Environmental Behavior}

The respondents agreed that buying products in a package that can be refilled is the most convenient for the consumers, it may lessen the trash and less damaging for the environment. As added, terms like recyclable, refillable, ozone friendly, and environmental friendly are some of the things that consumers most often associate with green marketing.

Green marketing encourages consumers to use eco-friendly products and manufacturers to develop more. The awareness about the products should be done through advertising so that individual buying behaviour can be changed which can have an impact on the welfare of the environment. In line with this, the result is evident that buying products in packages that can be refilled is creating an advantage because it's safe for the environment.

\section{Consumer Product}

The data indicates that buying products packaged that can be refilled can be useful and beneficial to nature. The respondents revealed that they gave attention to the product that can be used one or more times to save money. Revealed that the recycling system: the main goal of recycling is to allow the production of secondary materials which can be used instead of primary materials. This system saves money, reduces the production of new materials and reduces environmental impact [11].

According to the results, the majority of respondents encourage to buy green products because of their benefits to the environment. The respondents revealed that they are much more secure in their environmentally friendly purchase once they realize how goods benefit the environment.

The respondents revealed that they are much more secure in their environmentally friendly purchase once they realize how goods benefit the environment. It is revealed that consumers are willing to buy green products although this will somehow do not translate into actual purchases. The reason for this is that overpricing reduces a consumer's purchasing power [12]. Consumers become increasingly concerned about the environment and such concerns have begun to display in their purchasing patterns, with consumers increasingly preferring to buy so-called 'environmentally friendly products [8].

\section{Impacts of Green Marketing Practices on Consumer Buying Decision}

These findings show that the impact of green marketing can encourage to use of eco-friendly products, which got the first rank, make the environment safe which got the second rank, eco-friendly products are recyclable which got the third rank, and the last rank is reducing waste.

Data revealed that green marketing practices encourage consumers to use eco-friendly products. The results of the findings under rank 1 imply that the green marketing practices had an impact on the respondents buying behaviour. The respondents revealed that they encouraging patronizing green marketing and using eco-friendly products to lessen the impact on the environment. The respondents also added that they choose green marketing to contribute to environmental safety, reduce population and for a clean and green environment.

Companies have started their own strategies to fulfil consumer demands and introducing environmentally friendly products into the market, also known as Green Products [13]. When consumers become more mindful of environmental concerns, they are more likely to make environmentally friendly purchases. Marketers around the world are experimenting with and creating environmentally friendly goods in a number of categories to meet the needs of environmentally conscious customers.

Make the environment safe was also the impact of green marketing practices on consumer buying behaviour. It shows that consumers become more environmentally conscious and aware of the crisis facing the environment; therefore some of the respondents stated that green products contribute to the sustainability of the environment 
natural resources and reduce resources efficiency. The respondents also added the reason they choose green products because it was convincing due to the involvement of the safety of the environment.

It is stated that, environment and environmental problems, one of the reasons why green marketing emerged, are mentioned, and then the concepts of green marketing and green consumer are explained [9]. Environmental consciousness, green product features, green marketing practices, and green price, according to the findings, have a positive impact on consumers' green buying behaviours.

Eco-friendly products are recyclable it also the impact of green marketing practices, it shows that consumers attracted to products that can be benefited not only through the exact goods but also on its recyclable packaging they likely become creative and innovative consumers. The Respondents mentioned that they considered green marketing to offer a recyclable product. They also added that they prefer products beneficial to their selves and to Mother Nature.

It is verified that customers are becoming more concerned about environmental concerns and want to play a more active role in reducing the environmental effects of their decisions [14].

Lastly, reducing waste is one of the impacts of green marketing practices, most organizations become aware of harmful effects on the environment therefore they started to employ green marketing and introduce it to the market. The respondents encourage mobilizing green products for the reduction of waste.

Green initiatives are fast becoming a catchphrase among societies and business entities as these entities strive to ensure more sustainable business operations and lifestyle [15]. Normative values, social influence, and group esteem affect consumers' green purchase behavior [2]. It can aid businesses in raising awareness of green marketing and products, resulting in increased profits.

\section{CONCLUSION AND RECOMMENDATIONS}

Based on the majority of the findings of the respondents ages 25-29 years old and most of them were female and have no work with a monthly salary of $\mathrm{P} 5000$ and below. As an additional, most of the respondent agreed humans must live in harmony with nature in order to survive when it comes to general environmental beliefs. Most of the respondents stated that when it comes to environmental behaviour, no consumers or buyers should frequently buy which can be refilled. The majority of the respondents are highly in favour that they feel good about buying green brands causing less damage to our environment. Most of the respondents stated that using an eco-friendly product has the most impact of green marketing on consumer buying decision that contributes for the environment safety, they encourage patronizing green marketing and using eco-friendly products to lessen the negative impact in our environment.

Creating a campaign that provides information on how the environment will be benefited from the use of green products. Establish a standard of green packaging that illustrates the benefits of the environment in using such kind of packaging. By doing so, consumers that have different perspectives on green products will be more likely to make a habit of purchasing green products regardless of their price.

It is recommended to produce more refillable products that secondary material can be used. This system will save money for a consumer and less the cost of production of a business, and also this will lead to less impact on the environment.

Strengthening the campaign on green marketing practice through the use of different social media platforms. These platforms will help the marketers to connect with the customers and increase awareness of the crisis facing by the environment. A Social Media campaign is an efficient way to reach a large number of consumers because a billion people around the world use social media, the users and engagement on major platforms just keep growing. 


\section{References}

Bhardwaj, A., K., Garg, A., Ram, S., Gaypal Y., Zheng C., (2020, November 12), Research Trends in Green Product for Environment: A Bibliometric Perspective, Int. J. Environ. Res. Public Health 2020, 17, 8469; https://doi.org/10.3390/ijerph17228469

Khare, A, Mukerjee, S., Goyal, T. (2013, December 1). Social influence and green marketing: An exploratory study on Indian consumers. Journal of Customer Behaviour, Volume 12, Number 4, Winter 2013, pp. 361-381(21). https://doi.org/10.1362/147539213X13875568505903

Fluet, B. (2021, April 16). What Is Descriptive research? Retrieved from https://invoke.com/blog/what-is-descriptiveresearch.

StatTrek (2021). Voluntary Sample. Retrieved from

https://stattrek.com/statistics/dictionary.aspx?definition=voluntary\%20sample.

Tankovska, H. (2021, April 9). Percentage of adults in the United States who use social networks as of February 2019, by age group. Retrieved from https://www.statista.com/statistics/471370/us-adults-who-use-social-networks-age/

Kumaravel R. (2017, December). Consumer Shopping Behaviour and the Role of Women in Shopping-A Literature

Review Retrieved from

https://www.researchgate.net/publication/321862434_Consumer_Shopping_Behaviour_And_The_Role_Of_Women_In_S hopping-A_Literature_Review

Rutkowski, J. J.. (2015, December). Employment and Poverty in the Philippines. World Bank, Washington, DC. (C) World Bank. https://openknowledge.worldbank.org/handle/10986/26320 License: CC BY 3.0 IGO

Fisher, C., Bashyal, S., Bachman B. (2012, September 24). Demographic impacts on environmentally friendly purchase behaviors. J Target Meas Anal Mark 20, 172-184 (2012). https://doi.org/10.1057/jt.2012.13

Boztepe. A. (2012). Green Marketing and Its Impact on Consumer Buying Behavior. European Journal of Economic and Political Studies, 5(1)2012

Grande, J. J. (2017, January), Living in harmony with our environment: A paradigm shift. Disaster Resilience: An integrated approach ( $2^{\text {nd }}$ Ed). (pp. 289-307), Springfield I11

Babader, A., Ren, J., Jones, K. O., Wang, J. (2016). A system dynamics approach for enhancing social behaviours regarding the reuse of packaging. / Expert Systems With Applications 46 (2016) 417-425. Liverpool Logistics, Offshore and Marine (LOOM) Research Institute, Liverpool John Moores University, Liverpool, L3 3AF, UK. https://doi.org/10.1016/j.eswa.2015.10.025

Joshi, Y., Rahman, Z. (2015, December). Factors Affecting Green Purchase Behaviour and Future Research Directions. International Strategic Management ReviewVolume 3, Issues 1-2, June-December 2015, Pages $128-143$. https://doi.org/10.1016/j.ism.2015.04.001

Nazida, S. (2019, September). Consumer Buying Behaviour and Green Marketing Influence of Green Marketing on Buying Behaviour: Consumer Insights.

Fonseca, J. C. G. (2015). The Impact of Green Marketing Practices on Consumer Buying Decision. Master Dissertation in Business Administration

Eze, U. C., Ndubisi, N. O. (2013, August 8). Green Buyer Behavior: Evidence from Asia Consumers. Journal of Asian and African Studies, Volume: 48 issue: 4, page(s): 413-426. https://doi.org/10.1177/0021909613493602 